\title{
Diversity and ecology of rotifers in sadul branch of sirhind feeder, Hanumangarh (Rajasthan)
}

\author{
Mamta Sharmað, Rukasana \& Deepti Srivastava \\ Department of Zoology, Govt. Dungar College, Bikaner \\ 7 Corresponding author: M Sharma; E-mail: mamtasharma13884@gmail.com
}

Copyright (C2016 Sharma et al, This is an open access article published under the terms of the Creative Commons Attribution License, which permits unrestricted use, distribution, and reproduction in any medium, provided the original work is properly cited.

Preferred citation for this article: Sharma M, Rukasana \& Srivastava D. 2016. Diversity and ecology of rotifers in sadul branch of sirhind feeder, Hanumangarh (Rajasthan). Journal of Agriculture and Ecology, 1: 91-95; http://doi.org/10.53911/JAE.2016.1111.

\section{Abstract}

The Thar Desert is a desolated vast sandy stretch of inhospitable landscape. The ecology of this desert is characterized by harsh climatic conditions. For harnessing the harsh desert conditions, water is the most important component. To overcome adverse climatic conditions, the Sirhind Feeder was conceived in this region. Rotifers are one of the most important constituents of zooplankton community in fresh water ecosystem. These minute and delicate animals comprise an integral part in the aquatic food chain. Rotifers are hardy enough to tolerate extreme environmental conditions, features that place them in the class of best bioindicators of water quality. Present study was made to explore the diversity, density and ecology of rotifer fauna in sadul branch of Sirhind Feeder in Hanumangarh $\left(29^{\circ} 5^{\prime}\right.$ to $30^{\circ} 6^{\prime}$ north latitude and $74^{\circ} 3^{\prime}$ to $75^{\circ} 3^{\prime}$ east longitudes). The observations were made for a period of six months (January 2014 to June 2014). Physico-chemical conditions revealed that canal was shallow with turbid, well oxygenated, alkaline, hard and saline water. The study revealed the occurrence of seven species of rotifers represented by Keratella vulga, Keratella cochlearis, Brachionus bidentata, Brachionus calyciflorus, Filinia longiseta, Monostyla lunaris and Monostyla quadridentata. Rotifers were noted as peak population during the month of April (290 No./l).

Key Words: Rotifers, diversity and ecology, canal

\section{Introduction}

All the type of life, on the Earth depend upon water for their existence. Lotic habitats differ from the lentic habitat. Here current is a major controlling and liminting factor. Because of the abundance of the oxygen animal life is rich in the lotic habitat. The 
Thar desert is a desolated vast sandy stretch of inhospitable landscape. The ecology of this desert is characterized by harsh climatic conditions; water is the most important components. To overcome adverse climatic conditions, the Sirhind Feeder was conceived in this region. Rotifers are one of the most important constituents of zooplankton community in fresh water ecosystem. According to Dadhich \& Saxena (1999) the zooplankton plays an integral role and serves as bioindicators. It is a well suited tool for understanding water pollution status (Ahmad 1996; Contreras et al. 2009). Rotifers are minute and delicate animals comprise an integral part in the aquatic food chain. These are hardy enough to tolerate extreme environmental conditions, features that place them in the class of best bioindicators of water quality. It is usually observed that the greater population of the rotifers indicated in waters with eutrophification state of the reservoir. Further, it is the fact that the diversity of zooplankton is always less in the flowing fresh water compared to stagnant water like that of reservoir.

\section{Materials and Methods}

Hanumangarh is the northern most district of Rajasthan $\left(29^{\circ} 5^{\prime}\right.$ to $30^{\circ} 6^{\prime}$ north latitude and $74^{\circ} 3^{\prime}$ to $75^{\circ} 3$; east longitudes). Sadul branch is situated near by Jorkian village, Distt. Hanumangarh (Rajasthan). It is the part of Rajasthan Irrigation System (IGNP) under state government. The Sadul branch begins from Sirhind feeder at Rajasthan border situated at Punjab. The water of Sutlej river and Ravi-Vyas river (surplus water) flow in sadul branch. The study was carried out monthly in the period of six months i.e., January 2014 to June 2014. Water samples were collected from three study stations. Water was examined for the selected parameters including $\mathrm{pH}, \mathrm{EC}$, TDS, DO, hardness and alkalinity. For parameter like $\mathrm{pH}$, electrical conductance, total dissolve solids respective meters were used. Other parameter was analyzed in laboratory by using as per the standard method APHA-AWWA-WPCF (1981). The rotifers collected with plankton net made up of bolting silk (No. 25, mesh size $55 \mu$ ). The collected samples were carefully transferred to small bottle and preserved in freshly prepared $4 \%$ formaldehyde. Fauna was observed under a compound microscope. The forms were indentified and results were expressed in terms of No./l. The identification of fauna was made following Edmondson 1966; Michael 1973; Needham \& Needham 1978 and Tonapi 1980.

\section{Results and Discussion}

Physical-chemical limnology revealed that the canal was shallow with turbid, hard, saline, alkaline and well oxygenated water. $\mathrm{pH}$ of water ranged from 8.4 to 7.9 and average value was noted as 8.16. The average value of EC was recorded as 0.53 $\mathrm{mmho} / \mathrm{cm}$. Average of total dissolve solids was observed as $538.33 \mathrm{mg} / \mathrm{l}$. DO of water ranged from $8.94 \mathrm{mg} / \mathrm{l}$ to $30.49 \mathrm{mg} / \mathrm{l}$ and average value was noted as $19.10 \mathrm{mg} / \mathrm{l}$. Maximum hardness of water was recorded as $358 \mathrm{mg} / \mathrm{l}$ during the month of April and 
minimum reading was observed as $116 \mathrm{mg} / \mathrm{l}$ during the month of June and average value was noted as $206.66 \mathrm{mg} / \mathrm{l}$. Average value of alkalinity was recorded as $41 \mathrm{mg} / \mathrm{l}$.

During the present study Phylum Rotifera was represented by seven species Keratella vulga, Keratella cochlearis, Brachionus bidentata, Brachionus calyciflorus, Filinia longiseta, Monostyla lunaris and Monostyla quadridentata. The average value of rotifers was noted as 216.66 No./l. Among rotifers Monostyla quadridentata show the highest average value while keratella cochlearis shows lowest average value. Their population density was peak (290 No./l) during the month of April (moderate temperature) and least (160 No./l) during the month of May (maximum temperature).

Maximum population density of rotifers in April can be linked to the favourable temperature and availability of abundant food in the form of bacteria and suspended detritus. Saxena (2001) studied the rotifer fauna of the Indian desert and documented 17 species belonging to 11 genera. Srivastava (2009) reported six species of rotifers in some village pond ecosystem in the arid region of Rajasthan. Vaishali et al. (2012) reported 17 species of rotifers in Lake Kacharali, Thane (Maharashtra).

Arora \& Mehra (2003) while analysing seasonal dynamics of rotifers in relation to physic-chemical conditions of lotic water body made similar observation in increased densities in summer and reduced densities in winter. In summer, the absence of inflow of water brings stability to the water body. The availability of food is more due to production of organic matter and decomposition. These factors contribute for high species density.

Table 1. Physical-chemical variables at Sadul branch of Sirhind feeder, Hanumangarh during Jan, 2014-June, 2014. Values are average of three study stations and are expressed in $\mathrm{mg} / \mathrm{l}$ in water, except otherwise mentioned

\begin{tabular}{lccccccc}
\hline Variables & January & February & March & April & May & June & Average \\
\hline $\mathrm{pH}$ & 8.2 & 8.4 & 8.2 & 8.1 & 8.2 & 7.9 & 8.16 \\
EC mmho/cm & 0.48 & 0.50 & 0.56 & 0.57 & 0.55 & 0.57 & 0.53 \\
TDS & 480 & 500 & 560 & 570 & 550 & 570 & 538.33 \\
DO & 15.44 & 30.49 & 25.20 & 17.47 & 8.94 & 17.07 & 19.10 \\
Hardness & 186 & 170 & 160 & 358 & 250 & 116 & 206.66 \\
Alkalinity & 44 & 20 & 38 & 36 & 54 & 54 & 41.00 \\
\hline
\end{tabular}

Table 2. Diversity and population density of rotifers at sadul branch of Sirhind Feeder, Hanumangarh during January 2014 to June 2014. Value are averages of three study stations and are expressed as No./l.

\begin{tabular}{lccccccc}
\hline Rotifers & Jan & Feb & Mar & April & May & June & Average \\
\hline Keratella vulga & 20 & 30 & 50 & 40 & 20 & 40 & 33.33 \\
Keratella cochlearis & 30 & 40 & 20 & 40 & - & 30 & 26.66 \\
Brachionus bindentata & 40 & 20 & 10 & 50 & 20 & 40 & 30.00 \\
Brachionus calyciflorus & 20 & 40 & 50 & 40 & 30 & - & 30.00
\end{tabular}




\begin{tabular}{lccccccc} 
Filinia longiseta & 20 & 10 & 20 & 60 & 40 & 30 & 28.33 \\
Monostyla lunaris & 50 & 40 & 30 & 30 & 30 & 10 & 31.66 \\
Monostyla quandridentata & 40 & 60 & 20 & 30 & 20 & 40 & 35.00 \\
Total rotifers & 220 & 240 & 200 & 290 & 160 & 190 & 216.66 \\
\hline
\end{tabular}

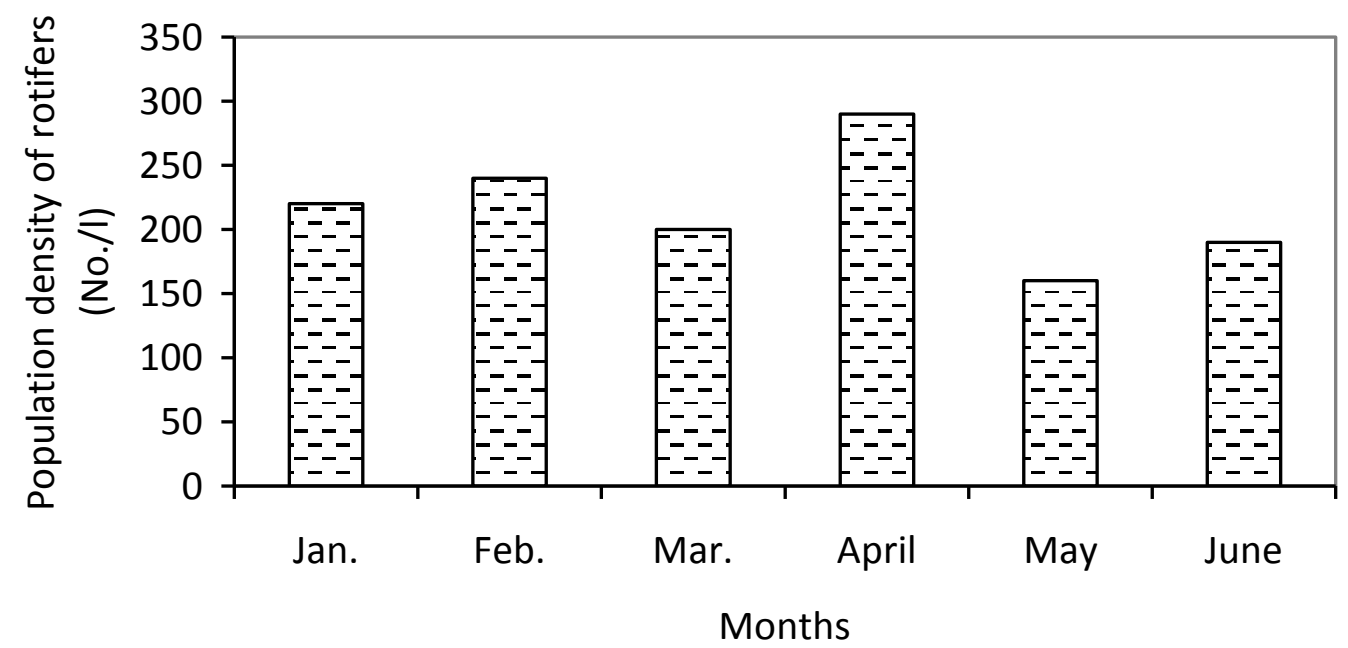

Fig. 1. Population density of rotifers at sadul branch of Sirhind Feeder, Hanumangarh (Rajasthan) during January 2014 to June 2014.

\section{Acknowledgement}

Authors are thankful to the Principal, Govt. Dungar College, Bikaner and the Head, Department of Zoology, Govt. Dungar College, Bikaner for providing necessary facilities at that time.

\section{References}

Ahmad MS. 1996. Ecological survey of some algal flora of polluted habitats of Darbhanga. Journal of Environmental Pollution, 3: 147-151.

APHA-AWWA-WPCF. 1981. Standard methods for the examination of water and waste water. 15 th Ed. APHA. Washington DC.

Arora J \& Mehra N. 2003. Seasonal dynamics of rotifers in relation to physical and chemical conditions of the river Yamuna (Delhi), India. Hydrobiologia, 49: 101-109.

Contreras JJ, Sarma SS, Merino-Ibarra M \& Nandini S. 2009. Seasonal Changes in the rotifer (Rotifera) diversity from a tropical high altitude reservoir Valle de bravo, Mexico. Journal of Environmental Biology, 30: 191-195.

Dadhich N \& Saxena MM. 1999. Zooplankton as indicators of trophical status of some desert waters near Bikaner. Journal of Environmental Pollutions, 6: 251254.

Edmondson WT. (ed.) 1966. Freshwater Biology. $2^{\text {nd }}$ Ed. John Wiley \& Sons, Inc., New York, USA. 
Michael RG. 1973. A guide to the study of fresh water organism. Journal of Madurai University, 1: 23-26.

Needham JG \& Needham PR. 1978. A guide to the study of fresh-water biology. Halden Day. Inc. Publ. San Francisco.

Saxena MM. 2001. Rotifer fauna of the Indian desert. Bionotes, (3) 4: 80-81.

Somani Vaishali, Quadros Goldin \& Pejaver Madhuri K. 2012. Studied the occurrence of rotifers and its relation to the water quality during the bioremediation process in lake Kacharali, Thane, MS, India. Journal of Biological Science, 1 (3): 54-58

Srivastava D. 2009. Faunal diversity and its ecology in some village pond ecosystem with special reference to insect fauna in the Indian desert. Ph.D. Thesis, M.G.S. University, Bikaner, 123.

Tonapi GT. 1980. Fresh water animals of India. Oxford and IBH Publ. Co., New Delhi, India. 